\title{
A Methodology Based on Magnetic Susceptibility to Characterize Copper Mine Tailings
}

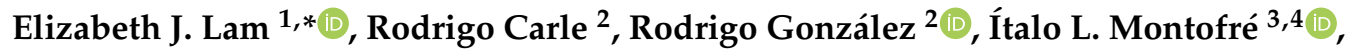 \\ Eugenio A. Veloso ${ }^{5}$, Antonio Bernardo ${ }^{6}$ (D), Manuel Cánovas 4 (D) and Fernando A. Álvarez ${ }^{3,7}$ \\ 1 Chemical Engineering Department, Universidad Católica del Norte, Antofagasta CP 1270709, Chile \\ 2 Geological Sciences Department, Universidad Católica del Norte, Antofagasta CP 1270709, Chile; \\ carlerodrigo@gmail.com (R.C.); r_gonzalez@ucn.cl (R.G.) \\ 3 Mining Business School, ENM, Universidad Católica del Norte, Antofagasta CP 1270709, Chile; \\ imontofre@ucn.cl (Í.L.M.); falvarez@ucn.cl (F.A.Á.) \\ 4 Mining and Metallurgical Engineering Department, Universidad Católica del Norte, \\ Antofagasta CP 1270709, Chile; manuel.canovas@ucn.cl \\ 5 Andean Geothermal Center for Excellence (CEGA), Departamento de Ingeniería Estructural y Geotécnica, \\ Pontificia Universidad Católica de Chile, Santiago 7560873, Chile; anveloso@ing.puc.cl \\ 6 Department of Mining Technology, Topography and Structures, Universidad de León, CP 24071 León, Spain; \\ antonio.bernardo@unileon.es \\ 7 Administration Department, Universidad Católica del Norte, Antofagasta CP 1270709, Chile \\ * Correspondence: elam@ucn.cl
}

Received: 28 August 2020; Accepted: 19 October 2020; Published: 22 October 2020

check for updates

\begin{abstract}
This paper intends to validate the application of magnetic techniques, particularly magnetic susceptibility, as sampling tools on a copper tailings terrace, by correlating them analytically. Magnetic susceptibility was measured in both the field and laboratory. Data obtained allowed for designing spatial magnetic susceptibility distribution maps, showing the horizontal variation of the tailings. In addition, boxplots were used to show the variation of magnetic susceptibility and the concentration of the elements analyzed at different depths of the copper tailings terrace. The degree of correlation between magnetic and chemical variables was defined with coefficient $\mathrm{R} 2$. The horizontal and vertical variations of magnetic susceptibility, the concentration of elements, and the significant correlations between them show a relationship between magnetic susceptibility and the chemical processes occurring in the tailing management facility, such as pyrite oxidation. Thus, the correlation functions obtained could be used as semiquantitative tools to characterize tailings or other mining residues.
\end{abstract}

Keywords: copper mine tailings; magnetic susceptibility; sampling; metals

\section{Introduction}

The treatment of extensively distributed solid wastes generated by metallurgical processes is a challenge for the environmental sustainability of mining regions [1,2]. Soil characterization is a relevant process for subsequent environmental treatments such as decontamination, stabilization, or remediation $[3,4]$. The physical ( $\mathrm{pH}$, density) and the chemical properties of soils are a forcing factor for the growth and pollutant metabolism of plants during phytoremediation, particularly heavy metal content in the sediments at the (superficial) upper levels [5,6]. In this context, heavy metal concentration is commonly determined by a chemical analysis involving a high cost and a long period of analysis [7-9]; however, a low-cost and fast-application method is necessary for effective sediment characterization prior to remediation.

For a reliable tailing storage facility characterization, a large number of sampling points is required so that results can be representative, a fact that has been limited due to the extensive economic 
resources needed. Sampling quality is essential for estimating the extent of contamination on-site and, therefore, establishing intervention requirements to protect human health and the ecosystem integrity [10]. In this regard, sampling design plays a fundamental role in the tailing characterization stage and must be based on the spatial contamination distribution hypothesis formulated from the results of the exploratory phase of the study. This allows for making an appropriate assessment of the site and its management [11,12]. It is necessary to design a sampling methodology to establish their presence in the mineral species contained in the tailings [13,14]. There are no general rules for soil sampling because each site requires a particular strategy. Therefore, it is important to design a scheme appropriate for each of the tailing storage facilities, considering the optimal location of the sampling points. This scheme must be flexible enough to make adjustments during field activities, owing to, for example, lack of access to preselected sites, unforeseen soil formations, and climatic conditions [15]. The characterization stage involves sampling and the analysis of physical and chemical properties to determine the nature, extent, and extension of contamination. These data are essential for developing, projecting, analyzing, and selecting cost effective technologies to mitigate contamination [16].

Magnetic techniques and methodologies are notable for characterizing soils since they can be validated with a small number of fast chemical analyses at a low cost $[17,18]$. Although the magnetic phenomenon was recognized in the early 19th century, its application in the different fields of science and technology has increased in the last few decades [19-21]. The magnetic characterization and mapping of the magnetic susceptibility of soils have been widely applied as a proxy to characterize heavy metals and pollutants in soils in urban and industrial areas [22-29]. This type of study allows for determining the origin and extension of contaminant agents and their effect on natural soils. Magnetic properties, particularly magnetic susceptibility, are useful tools for identifying and describing ferromagnetic elements ( $\mathrm{Fe}, \mathrm{Ni}, \mathrm{Cr}$ ). They allow an indirect characterization of the study area because a small number of chemical analyses are needed later.

Magnetic susceptibility is the ability of a material to magnetize itself under the effect of an induced magnetic field, which has a range of values characteristic of the different ferromagnetic elements. It is possible to measure this property in the field by using easy-to-use portable susceptometers at a low cost [30]. Despite the wide use of magnetic techniques for natural soil contamination, they have been scarcely used for detecting and determining the concentration of metals present in tailing deposits [31]. Therefore, the application of magnetic techniques is a good alternative for the chemical characterization of tailing storage facilities due to their high resolution and low cost. In addition, these techniques have important advantages such as short measurement time and the repetition of analyses at a low cost.

Several factors take part in the control of the retention and mobility of heavy metals in the soil, mineralogy playing an important role among them [32]. The bioavailability of most of the elements, particularly heavy metals, is determined by adsorption-desorption, complexation, precipitation, and ion-change processes. The most important surfaces involved in soil metal adsorption are active inorganic colloids such as clayey minerals, metal oxides and hydroxides, metal carbonates and phosphates, and organic colloids [33]. Regarding texture, clayey soils retain more metals by adsorption or in the exchange complex of the clayey minerals; on the contrary, sandy soils lack this fixing capacity. In particular, each clay mineral is characterized by a specific surface area value and a degree of electrical decompensation, which influence its ability to adsorb or exchange metals [34].

Chilean mining is paramount for the country's development and has become part of its identity. Chile has become a world's copper production leader, with mining being the productive activity contributing most to GDP [35]. However, it also holds a negative aspect due to the large output of residues and toxic wastes resulting from different operations and processes. Copper sulfide ore processing produces residues called tailings, which contain high heavy metal concentrations [36]. Many solid tailing deposits extend for kilometers, their characterization currently being made via chemical analyses at a high cost [9]. There are 742 mine tailing disposal sites in Chile; some of them are abandoned and require an urgent management plan [37]. To propose remediation plans in order to reduce potential risks associated with tailings, their physicochemical and mineralogical characterization 
is a priority. These data are not available or are rather scarce, as in the case of geochemical data reported by National Geology and Mining Service (SERNAGEOMIN, for its acronym in Spanish) that determined the geochemical characterization of a number of tailing disposal facilities, based on samples from one to four sampling points [10].

The aim of this work is to discard or validate magnetic susceptibility measurement as a technique for determining the contaminants, concentrations, and/or mobility of the elements in tailing storage facilities. This study, conducted by examining copper mine tailings, intends to validate the techniques measuring magnetic properties as sampling tools, correlating them with a limited number of physicochemical analyses. The objective of this study is to validate the measurement of magnetic susceptibility in the tailing terrace of a copper porphyry-type ore deposit. To attain the objective, heavy metal concentration values in the tailings are correlated with magnetic susceptibility to determine if this technique can be used as a fast and cost effective tool for identifying contaminated areas. Our results are relevant and offer a low cost and effective method to characterize solid wastes generated by copper metallurgical processes prior to their management and treatment in an extensive mining region like northern Chile.

\section{Methodology}

\subsection{Site}

This study was conducted in the Atacama Desert, located in Antofagasta Region, Chile. This region is characterized by high solar radiation, high saline soil concentrations, extremely high daytime temperatures, and a wide day-night temperature range. Some areas of the Atacama Desert show zero recorded rainfall in 400 years. In general, rainfall occurs every 100 years. All these conditions produce scarce vegetation. Samples were collected from a copper mine tailings site located at latitude $24^{\circ} 9^{\prime} 58.33^{\prime \prime} \mathrm{S}$ and longitude $69^{\circ} 2^{\prime} 33.36^{\prime \prime} \mathrm{W}$, at 3200 masl The terraces where the tailings are disposed show high concentrations of heavy metals such as $\mathrm{Cu}, \mathrm{Cd}, \mathrm{Fe}, \mathrm{Zn}, \mathrm{Mn}$, and $\mathrm{Pb}$ because the tailings are generated in the sulfide concentration process. The total area of the terrace is about $10,000 \mathrm{~m}^{2}(135 \mathrm{~m} \times$ $77 \mathrm{~m}$ ). This site was used as a tailings dump from 1995 to 2006. Figure 1A,B shows the location of the tailings called CMZ.
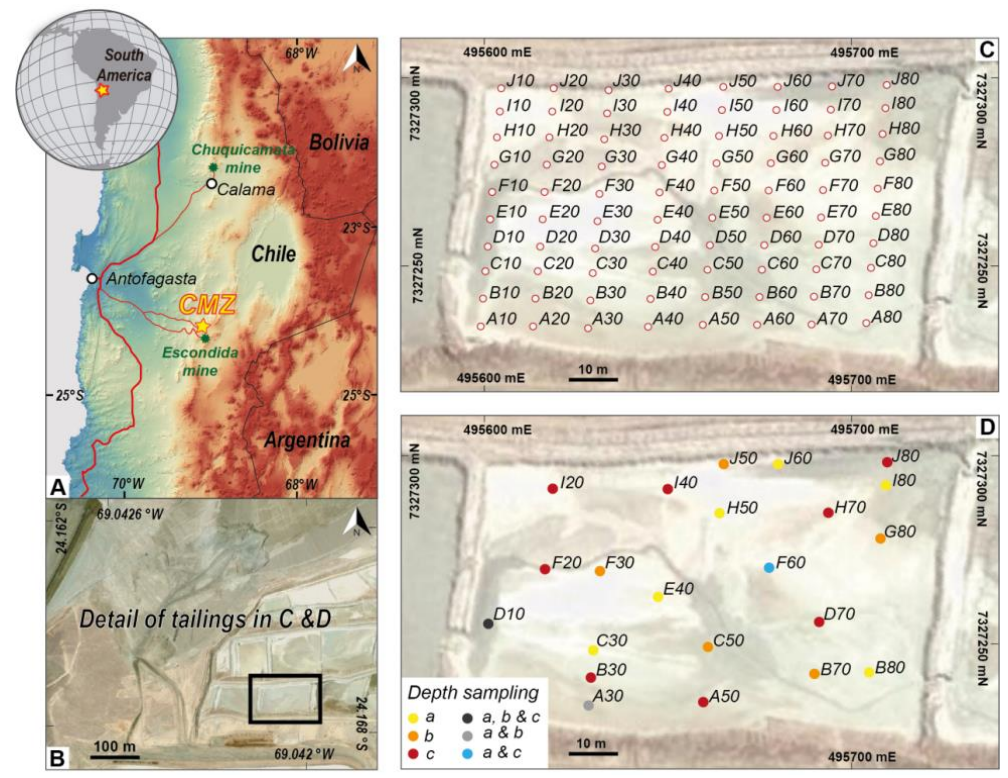

Figure 1. (A,B) CMZ tailings location, (C) regular sampling grid with 80 sites on CMZ tailings, (D) spatial distribution of tailings samples for chemical analyses. Green: depth a; blue: depth b; red: depth c; purple: three depths; yellow: depths a and b; light blue: depths a and c. The black box represents the study area within the tailing terrace. 
CMZ is a copper porphyry with low-grade hypogenic mineralization, where a long continuous supergene enrichment process favored by the predominating tectonic regime during the Upper Oligocene-Lower Miocene [38,39] resulted in the formation of economically exploitable ore deposits. The later decrease of the erosion rate and the increase of regional aridity since the Middle Miocene allowed for the preservation of these ore deposits [40]. Intrusive Oligocene, genetically related to CMZ, includes an early phase of rhyolitic porphyries associated with mineralization and a more intense hypogenic alteration. The later phase corresponds to dioritic porphyries.

According to its mineralization, the ore deposit consists of an upper leached zone associated with quartz-sericitic and copper oxide traces; an oxidation area with brochantite and antlerite; and an extremely sericitized secondary rich zone consisting of pyrite, chalcocine, bornite, covelline, and chalcopyrite. The hypogenic mineralization associated with sericitic alteration and a weak silicification consists mainly of pyrite with small amounts of bornite, chalcopyrite, and molybdenite.

\subsection{Sampling In Situ}

To collect the samples, the terrace was divided into a grid of $15 \mathrm{~m} \times 7 \mathrm{~m}$, covering an internal area of $6615 \mathrm{~m}^{2}$, to create 80 equidistant sampling points, as shown in Figure 1C. Due to the rough terrain and to facilitate sample collection, the profiles corresponding to the external points of the terrace were not considered. For the 80 internal points, magnetic susceptibility intensity was measured at three different depths: depth a (0-10 cm deep); depth b (10-20 cm deep); and depth c (20-30 cm deep). This property was used to estimate the points with larger metal concentrations [41]. According to this criterion, 33 sample points were selected.

The samples were collected at the first $30 \mathrm{~cm}$, considering characterization as the preliminary analysis of a phytoremediation system. Plant growth and trace element absorption generally occurred at a $10-30 \mathrm{~cm}$ depth [42-44].

\subsubsection{Sampling Grid Design}

The tailings terrace studied is $160 \mathrm{~m}$ long and $80 \mathrm{~m}$ wide (Figure 1C). For the sampling to include the whole study area, a regular grid was designed, with a $7 \mathrm{~m}$ support in the direction of the tailings walls (N05E), while in the W-E direction, they are at a $15 \mathrm{~m}$ distance from each other, heading N85E. This area was chosen according to the terrace dimensions so that the sampling could be representative in both directions (nonrandom sampling).

Distances were measured with a $60 \mathrm{~m}$ measuring tape, while the direction was obtained with a Brunton compass. The sampling grid was integrated into a geographic data system over a rectified Quickbird image from Google Earth, using ArcGis 10 software.

\subsubsection{Sampling}

From each tailings sediment site, $1 \mathrm{~kg}$ was obtained. The total number of samples amounted to 240 . The sediment was extracted with a plastic shovel to avoid altering magnetic measurements. Later, the material collected was stored in clean sealed polyethylene bags, labeled according to site and depth. Table 1 exemplifies the spatial identification of each tailings sample.

Table 1. Example of sample identification.

\begin{tabular}{ccccc}
\hline Type of Sample & Depth (cm) & Sampling Site & $\begin{array}{c}\text { Depth } \\
\text { Identification }\end{array}$ & $\begin{array}{c}\text { Final } \\
\text { Identification }\end{array}$ \\
\hline \multirow{2}{*}{ Disaggregated } & $0-10$ & A10 & $\mathrm{a}$ & A10 a \\
material & $10-20$ & A10 & b & A10 b \\
& $20-30$ & A10 & C & A10 c \\
\hline
\end{tabular}




\subsection{Measurement Methodology}

\subsubsection{Magnetic Susceptibility Measurement}

Magnetic susceptibility measurements were made with an SM-30 portable susceptometer (Heritage Geophysics, Littleton, CO, USA) to make quick measurements in the field with a $1 \times 10^{-7}$ magnetic susceptibility (SI) precision. The measurements were made on dry samples, using the mode 517 of the device at a $43.8 \mathrm{~cm}^{3}$ fixed volume. Magnetic susceptibility measurements were made at the three depths of the 80 sampling points. At each sampling depth, magnetic susceptibility was measured three times at different points. It was possible to check the validity of the susceptometer data by repeating measurements by horizon. Next, the average value was obtained.

\subsection{2. $\mathrm{pH}$ Measurement}

$\mathrm{pH}$ was measured in situ with a $\mathrm{pH} /{ }^{\circ} \mathrm{C}$ measuring kit, Model HI 99121 (Hanna Instruments, Woonsocket, RI, USA), which is used for measuring both soil $\mathrm{pH}$ and a solution prepared with a soil sample directly.

\subsubsection{Heavy Metal Concentration Determination}

A total of 33 sampling points were selected for chemical analysis. To do this, the following criteria were considered:

(1) Tailings $\mathrm{pH}$ variation; this property conditions metal bioavailability.

(2) Magnetic susceptibility variation in tailings sediments; samples were selected to make a representative subsampling of all the values observed in the distribution of this property.

(3) The three depths were established so as to obtain representative results of the whole tailings volume.

Substrate samples, properly labeled and packed in polyethylene bags, were collected. They were oven-dried at $40^{\circ} \mathrm{C}$ until reaching a constant weight $[45,46]$. Gravel-sized rocks $(>2 \mathrm{~mm})$ were removed and the remaining particles reduced in size with mortar and pestle. Particles were then screened with a 2-mm sieve (US N $\mathrm{N}^{\circ} 10$ mesh), which is the standard particle size for most soil testing methods [45,47].

Bioavailable $\mathrm{Fe}, \mathrm{Mn}, \mathrm{Zn}, \mathrm{Cr}, \mathrm{Cu}, \mathrm{Cd}$, and $\mathrm{Pb}$ contents were measured with an atomic absorption spectrophotometer (AAS) after extraction by using a diethylenetriaminepentaacetic acid (DTPA) solution [48]. These metals were collected by shaking $0.01 \mathrm{~kg}$ of oven-dried soil for $2 \mathrm{~h}$ in $20 \mathrm{~mL}$ of $0.005 \mathrm{M}$ DTPA. The filtrate was analyzed for $\mathrm{Fe}, \mathrm{Mn}, \mathrm{Zn}, \mathrm{Cr}, \mathrm{Cu}, \mathrm{Cd}$, and $\mathrm{Pb}$ by AAS. Cadmium, copper, chromium, lead, zinc, and iron were measured by ASS, with detection limits of $0.05 \mathrm{mg} \mathrm{kg}^{-1}$ for Cd, $\mathrm{Cr}$ and $\mathrm{Zn}, 4.3 \mathrm{mg} \mathrm{kg}^{-1}$ for $\mathrm{Pb}, 7.5 \mathrm{mg} \mathrm{kg}^{-1}$ for $\mathrm{Cu}$, and $24 \mathrm{mg} \mathrm{kg}^{-1}$ for Fe. As analysis was conducted separately by hydride generation-atomic absorption spectrometry (HGAAS). Hydride was generated by using a Perkin-Elmer 100 FIAS FIA 100 apparatus ( $0.005 \mathrm{mg} \mathrm{kg}^{-1}$ detection limit). All solutions were filtered with Whatman GF/C fiberglass filter paper [9].

\section{Results}

Data selected according to the three criteria above (Section 2.3.3) are shown in Table 2. The spatial distribution of the sampling points for the three depths are shown in Figure 1C.

Tables 3-5 show the results of the concentration analyses of eight heavy metals (As, Cd, Cr, Cu, Fe, $\mathrm{Ni}, \mathrm{Pb}$, and $\mathrm{Zn}$ ) and the magnetic susceptibility (MS) values for the three points measured in the field. The denomination is based on the names of the wells and the sampling depth, as shown in Table 1. 
Table 2. Samples selected according to $\mathrm{pH}$ classes and magnetic susceptibility variability.

\begin{tabular}{|c|c|c|c|c|}
\hline Depth & pH Range & Sample & $\mathrm{pH}$ & Soil K $(\mu \mathrm{SI})$ \\
\hline \multirow{11}{*}{ Depth a $0-10 \mathrm{~cm}$} & $\mathrm{pH}<5$ & A30 & 3.65 & 389.3 \\
\hline & \multirow{6}{*}{$5<\mathrm{pH}<6.5$} & B80 & 5.45 & 532.7 \\
\hline & & C30 & 5.32 & 655.3 \\
\hline & & D70 & 5.43 & 672.0 \\
\hline & & $\mathrm{H} 50$ & 5.65 & 619.7 \\
\hline & & $\mathrm{I} 20$ & 5.12 & 735.0 \\
\hline & & J60 & 5.97 & 334.3 \\
\hline & \multirow{3}{*}{$6.5<\mathrm{pH}<7.5$} & E40 & 6.54 & 520.0 \\
\hline & & $\mathrm{F} 60$ & 7.20 & 655.3 \\
\hline & & I80 & 6.97 & 679.0 \\
\hline & $\mathrm{pH}>7.5$ & D10 & 7.99 & 488.0 \\
\hline \multirow{11}{*}{ Depth b 10-20 cm } & \multirow{7}{*}{$5<\mathrm{pH}<6.5$} & A30 & 5.79 & 618.3 \\
\hline & & $\mathrm{B} 70$ & 5.58 & 1090.0 \\
\hline & & D70 & 5.92 & 991.0 \\
\hline & & $\mathrm{E} 40$ & 6.12 & 297.0 \\
\hline & & E70 & 6.18 & 256.8 \\
\hline & & G80 & 6.35 & 826.0 \\
\hline & & $\mathrm{I} 20$ & 6.17 & 583.0 \\
\hline & \multirow{3}{*}{$6.5<\mathrm{pH}<7.5$} & C50 & 6.58 & 393.0 \\
\hline & & F30 & 6.89 & 637.0 \\
\hline & & $\mathrm{J} 50$ & 7.02 & 490.3 \\
\hline & $\mathrm{pH}>7.5$ & D10 & 7.97 & 326.7 \\
\hline \multirow{11}{*}{ Depth c 20-30 cm } & $5<\mathrm{pH}<6.5$ & $\mathrm{I} 40$ & 6.35 & 272.7 \\
\hline & \multirow{8}{*}{$6.5<\mathrm{pH}<7.5$} & A50 & 7.50 & 186.0 \\
\hline & & D70 & 6.82 & 434.3 \\
\hline & & $\mathrm{E} 40$ & 6.95 & 160.0 \\
\hline & & F20 & 7.30 & 816.0 \\
\hline & & $\mathrm{F} 60$ & 7.12 & 682.7 \\
\hline & & $\mathrm{H} 70$ & 6.93 & 1159.0 \\
\hline & & $\mathrm{I} 20$ & 6.98 & 369.3 \\
\hline & & J80 & 7.07 & 246.3 \\
\hline & \multirow{2}{*}{$\mathrm{pH}>7.5$} & B30 & 7.59 & 364.0 \\
\hline & & D10 & 7.61 & 479.0 \\
\hline
\end{tabular}

Table 3. Results of chemical analyses for the first stratum at a $0-10 \mathrm{~cm}$ depth.

\begin{tabular}{|c|c|c|c|c|c|c|c|c|c|}
\hline \multirow{2}{*}{ Site } & $\mathrm{Cd}$ & As & $\mathrm{Zn}$ & $\mathrm{Cu}$ & $\mathrm{Fe}$ & $\mathrm{Ni}$ & $\mathbf{P b}$ & $\mathrm{Cr}$ & \multirow{2}{*}{$\begin{array}{c}\text { Soil K } \\
\mu \mathrm{SI}\end{array}$} \\
\hline & \multicolumn{8}{|c|}{$\mathrm{mg} \cdot \mathrm{kg}^{-1}$} & \\
\hline $\mathrm{A} 30 \mathrm{a}$ & 2.09 & 26.3 & 426.7 & 12,118 & 33,050 & 58.3 & 412.3 & 27.2 & 389.3 \\
\hline B80 a & 2.10 & 33.6 & 446.4 & 10,395 & 36,913 & 96.2 & 452.3 & 29.3 & 532.7 \\
\hline C30 a & 1.90 & 28.3 & 473.2 & 12,090 & 34,653 & 77.3 & 376.6 & 41.2 & 655.3 \\
\hline D10 a & 2.60 & 21.8 & 398.8 & 14,426 & 31,278 & 68.4 & 420.2 & 17.6 & 488.0 \\
\hline D70 a & 3.20 & 21.9 & 306.6 & 9323 & 41,923 & 67.2 & 289.5 & 14.8 & 672.0 \\
\hline $\mathrm{E} 40 \mathrm{a}$ & 2.80 & 32.1 & 287.2 & 8225 & 33,607 & 88.2 & 322.2 & 32.4 & 520.0 \\
\hline F60 a & 4.10 & 27.3 & 327.6 & 8454 & 34,756 & 59.6 & 254.2 & 29.5 & 655.3 \\
\hline $\mathrm{H} 50 \mathrm{a}$ & 3.70 & 21.8 & 333.6 & 8857 & 35,656 & 72.3 & 322.1 & 19.3 & 619.7 \\
\hline $\mathrm{I} 20 \mathrm{a}$ & 2.40 & 32.5 & 328.8 & 12,160 & 36,675 & 49.4 & 312.2 & 22.4 & 735.0 \\
\hline I80 a & 4.20 & 20.6 & 425.3 & 9519 & 38,137 & 88.2 & 453.8 & 26.7 & 679.0 \\
\hline $\mathrm{J} 60 \mathrm{a}$ & 2.80 & 23.4 & 399.5 & 10,712 & 33,716 & 77.3 & 408.1 & 33.9 & 334.3 \\
\hline
\end{tabular}


Table 4. Results of chemical analyses for the second stratum at a $10-20 \mathrm{~cm}$ depth.

\begin{tabular}{|c|c|c|c|c|c|c|c|c|c|}
\hline \multirow{2}{*}{ Site } & $\mathrm{Cd}$ & As & $\mathrm{Zn}$ & $\mathrm{Cu}$ & $\mathrm{Fe}$ & $\mathrm{Ni}$ & $\mathrm{Pb}$ & $\mathrm{Cr}$ & \multirow{2}{*}{$\begin{array}{c}\text { Soil K } \\
\mu \mathrm{SI}\end{array}$} \\
\hline & \multicolumn{8}{|c|}{$\mathrm{mg} \cdot \mathrm{kg}^{-1}$} & \\
\hline $\mathrm{A} 30 \mathrm{~b}$ & 0.848 & 21.2 & 373.7 & 10,728 & 34,470 & 32.5 & 221.2 & 17.3 & 618.3 \\
\hline $\mathrm{B} 70 \mathrm{~b}$ & 1.187 & 18.3 & 375.3 & 8231 & 33,219 & 34.6 & 245.2 & 12.8 & 1090.0 \\
\hline $\mathrm{C} 50 \mathrm{~b}$ & 0.699 & 15.6 & 207.7 & 10,321 & 30,846 & 28.3 & 282.8 & 21.4 & 393.0 \\
\hline $\mathrm{D} 10 \mathrm{~b}$ & 0.899 & 18.2 & 450.8 & 12,658 & 31,950 & 41.2 & 198.4 & 19.4 & 326.7 \\
\hline D70 b & 0.599 & 22.4 & 280.3 & 16,296 & 34,781 & 19.6 & 187.5 & 18.6 & 991.0 \\
\hline $\mathrm{E} 40 \mathrm{~b}$ & 0.900 & 23.9 & 240.6 & 14,533 & 31,733 & 22.2 & 201.4 & 22.6 & 297.0 \\
\hline $\mathrm{E} 70 \mathrm{~b}$ & 0.352 & 21.2 & 200.1 & 14,701 & 27,625 & 28.3 & 167.4 & 21.9 & 256.8 \\
\hline $\mathrm{F} 30 \mathrm{~b}$ & 0.798 & 28.3 & 500.6 & 9003 & 37,297 & 32.2 & 135.3 & 18.2 & 637.0 \\
\hline G80 b & 2.298 & 12.4 & 271.2 & 17,203 & 36,731 & 31.4 & 194.9 & 19.6 & 826.0 \\
\hline $\mathrm{I} 20 \mathrm{~b}$ & 1.797 & 15.6 & 300.9 & 11,096 & 37,095 & 17.8 & 217.8 & 14.3 & 583.0 \\
\hline $\mathrm{J} 50 \mathrm{~b}$ & 2.298 & 17.8 & 299.5 & 12,398 & 38,489 & 28.2 & 175.9 & 18.8 & 490.3 \\
\hline
\end{tabular}

Table 5. Results of chemical analyses for the third stratum at a $20-30 \mathrm{~cm}$ depth.

\begin{tabular}{|c|c|c|c|c|c|c|c|c|c|}
\hline \multirow{2}{*}{ Site } & $\mathrm{Cd}$ & As & $\mathrm{Zn}$ & $\mathrm{Cu}$ & $\mathrm{Fe}$ & $\mathbf{N i}$ & $\mathrm{Pb}$ & $\mathrm{Cr}$ & \multirow{2}{*}{$\begin{array}{c}\text { Soil KS } \\
\text { KS }\end{array}$} \\
\hline & \multicolumn{8}{|c|}{$\mathrm{mg} \cdot \mathrm{kg}^{-1}$} & \\
\hline A50 c & 0.698 & 10.8 & 225.4 & 9186 & 30,433 & 12.8 & 222.7 & 13.6 & 186.0 \\
\hline $\mathrm{B} 30 \mathrm{c}$ & 0.897 & 17.3 & 288.3 & 9798 & 35,816 & 23.9 & 198.6 & 17.2 & 364.0 \\
\hline D10 c & 1.800 & 15.4 & 458.5 & 12,207 & 37,001 & 21.8 & 178.5 & 17.4 & 479.0 \\
\hline D70 c & 0.797 & 14.1 & 190.9 & 8181 & 23,457 & 17.5 & 218.7 & 9.6 & 434.3 \\
\hline $\mathrm{E} 40 \mathrm{c}$ & 0.900 & 18.3 & 200.5 & 8234 & 30,839 & 19.8 & 218.4 & 22.5 & 160.0 \\
\hline F 20c & 2.791 & 28.3 & 495.4 & 9452 & 41,652 & 21.4 & 198.4 & 18.4 & 816.0 \\
\hline F60 c & 2.342 & 17.9 & 394.4 & 10,247 & 36,012 & 31.2 & 219.2 & 28.3 & 682.7 \\
\hline $\mathrm{H} 70 \mathrm{c}$ & 2.021 & 15.8 & 313.5 & 13,939 & 33,667 & 18.9 & 178.9 & 12.4 & 1159.0 \\
\hline $\mathrm{I} 20 \mathrm{c}$ & 2.396 & 13.8 & 483.2 & 12,591 & 39,608 & 24.8 & 228.9 & 17.2 & 369.3 \\
\hline $\mathrm{I} 40 \mathrm{c}$ & 1.879 & 21.2 & 393.5 & 13,872 & 39,540 & 22.9 & 178.4 & 21.9 & 272.7 \\
\hline $\mathrm{J} 80 \mathrm{c}$ & 2.394 & 17.4 & 328.4 & 14,171 & 34,704 & 17.9 & 189.6 & 19.4 & 246.3 \\
\hline
\end{tabular}

\subsection{Relationship between Magnetic Susceptibility and Depth}

Considering the 240 samples, there is a statistical correlation between sampling depth and magnetic susceptibility. For the three depths, the standard deviation and the variance show high values, indicating a high dispersion of the magnetic susceptibility data measured. The mean value of magnetic susceptibility for the three horizons tends to 411-518 $\mu \mathrm{SI}$, showing a decrease in depth, as illustrated in Figures 2 and 3, showing a boxplot and an interval plot, respectively. Given a certain relationship between depth and magnetic susceptibility, a hypothesis test was conducted.

The relationship between MS and depth was analyzed with ANOVA. This test shows the influence of one or more factors, in this case depth, over the mean of a continuous variable, in this case MS. Table 6 shows the mean, standard deviation, and $95 \%$ CI for the mean of each profile. The ANOVA test was conducted with a $95 \%$ CI. Results reveal statistically significant differences between at least two groups $(\mathrm{df}=2 ; \mathrm{F}=7.85 ; p$-value $=0.001)$. According to the results of the Tukey's post hoc test [49], the group under $30 \mathrm{~cm}$ present statistically significant differences in the magnetic susceptibility mean when compared with the other two. 


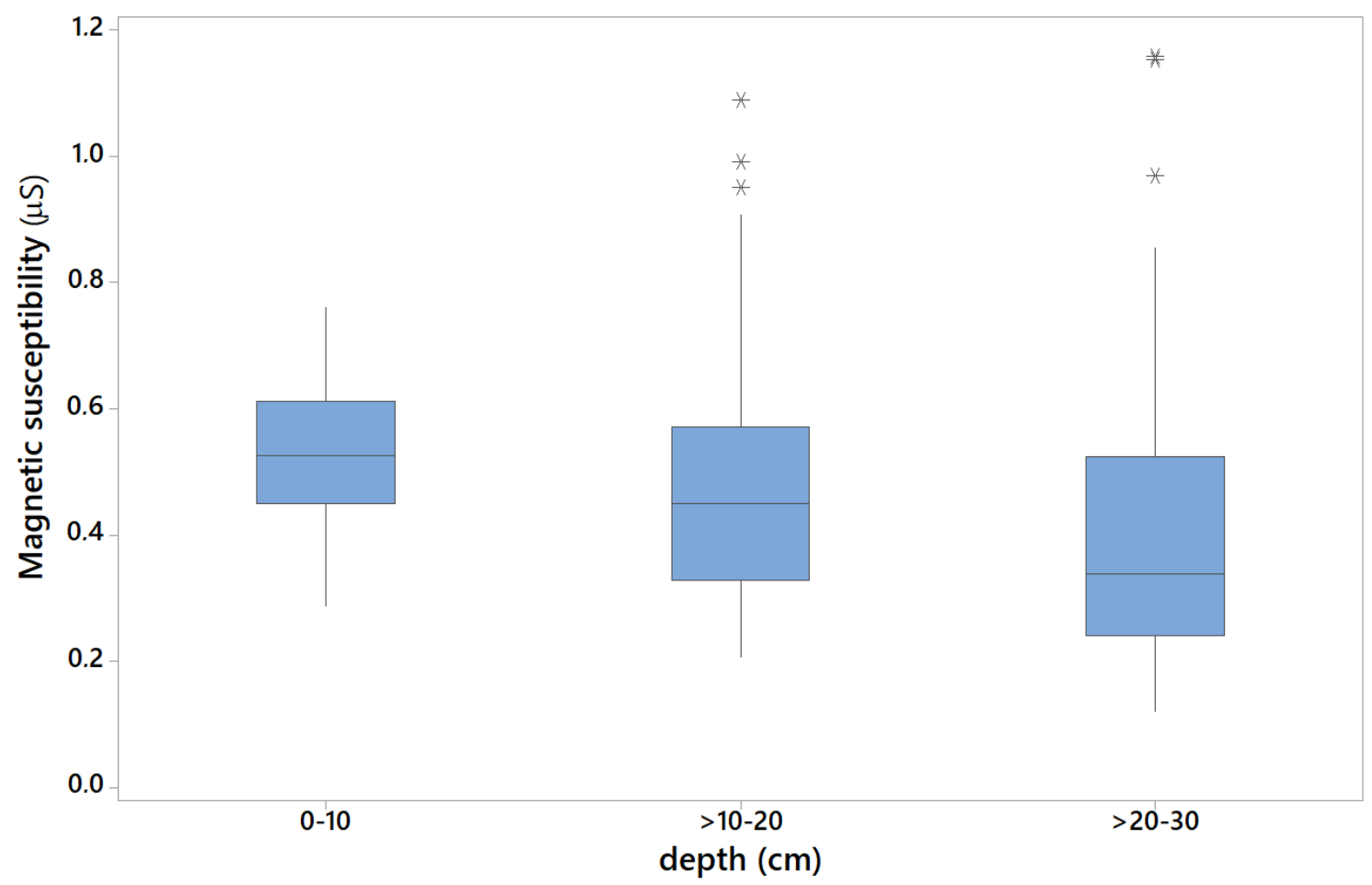

Figure 2. Boxplots for magnetic susceptibility (MS) values at three sampling depths.

95\% Cl for the Mean

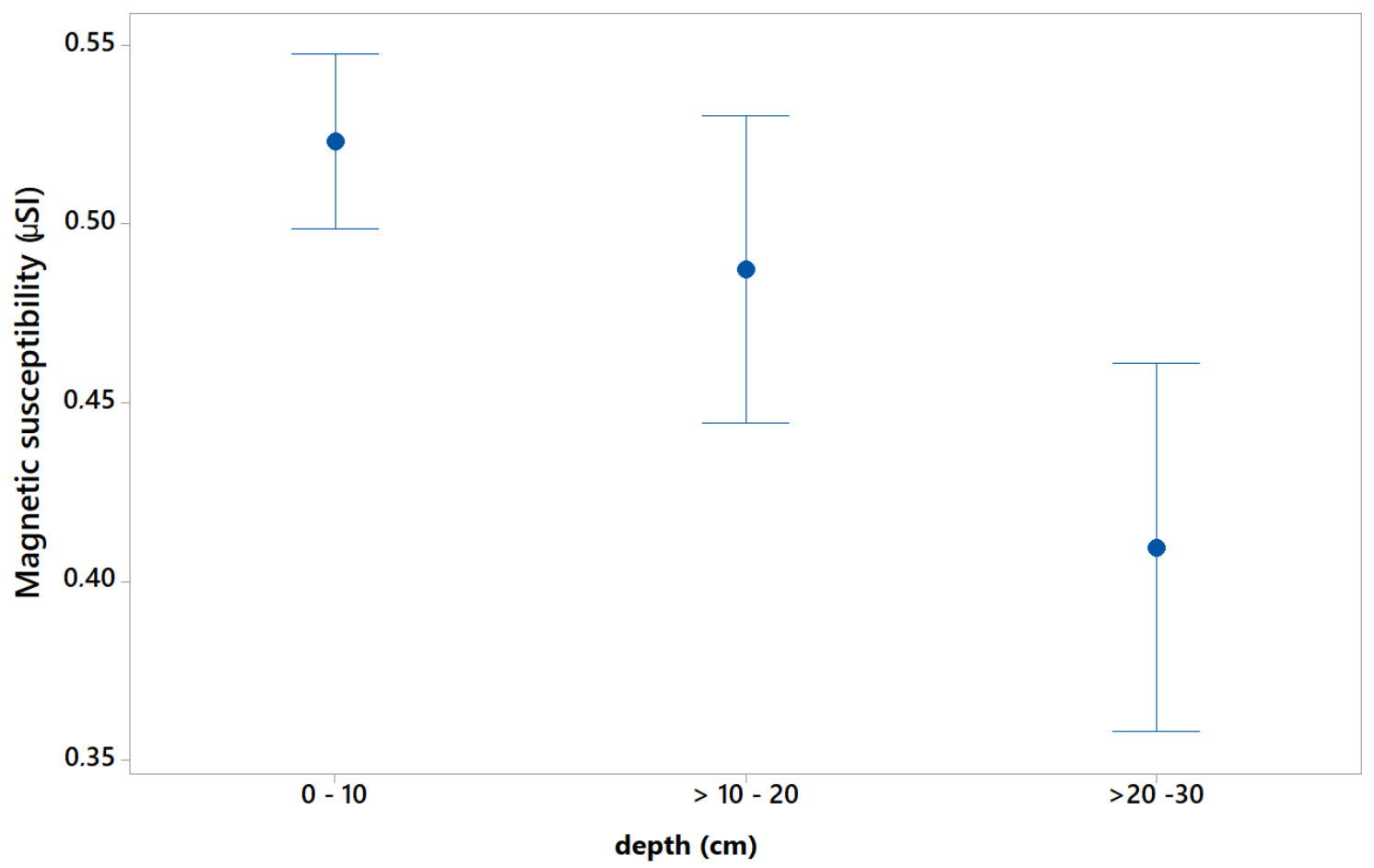

Figure 3. MS values at three sampling depths for a $95 \%$ confidence interval (CI). 
Table 6. Mean value, standard deviation, and confidence interval per sample depth.

\begin{tabular}{cccc}
\hline Profile & Mean & SD & 95\% CI \\
\hline $0-10 \mathrm{~cm}$ & 0.5230 & 0.1100 & $(0.4822 ; 0.5638)$ \\
$10-20 \mathrm{~cm}$ & 0.4872 & 0.1934 & $(0.4464 ; 0.5280)$ \\
$20-30 \mathrm{~cm}$ & 0.4095 & 0.2311 & $(0.3687 ; 0.4503)$ \\
\hline
\end{tabular}

\subsection{Relationship between Magnetic Susceptibility and $p H$}

MS decreases as tailing depth increases. Kapikca et al. [50], Hoffmann et al. [51], Boyko et al. [52], and Magiera et al. [53] observed this tendency, associated with the enrichment of anthropogenic particles on the most superficial layers of the soil from nearby industries or plants. The main difference between this study and those mentioned above is the type of soil where samples are collected, since samples are taken from the tailings mass in this study. For this reason, MS decrease is related to chemical processes occurring within the tailings. MS decrease with depth may be explained by the most important reaction in the tailings, i.e., pyrite oxidation (Equations (1)-(3)). As explained by Dold and Fontboté [54], atmospheric oxygen eruption into the system begins sulfide oxidation, in this case pyrite, the main gangue in the ore deposit.

$$
\begin{gathered}
\mathrm{FeS}_{2}+\frac{7}{2} \mathrm{O}_{2}+\mathrm{H}_{2} \mathrm{O} \rightarrow \mathrm{Fe}^{+2}+2 \mathrm{SO}_{4}^{2-}+2 \mathrm{H}^{+} \\
\mathrm{Fe}^{+2}+\frac{1}{4} \mathrm{O}_{2}+\mathrm{H}^{+} \rightarrow \mathrm{Fe}^{3+}+\frac{1}{2} \mathrm{H}_{2} \mathrm{O} \\
\mathrm{Fe}^{3+}+3 \mathrm{H}_{2} \mathrm{O} \rightarrow \mathrm{Fe}(\mathrm{OH})_{3}+3 \mathrm{H}^{+}
\end{gathered}
$$

Pyrite oxidation is the main acidity producer of the system (Equation (1)). The acidity produced by these processes may result in a $\mathrm{pH}$ decrease [55-59]. Tailings from copper porphyry-type ore deposits show $1-3 \%$ pyrite concentrations [54]. Therefore, ions such as $\mathrm{Fe}^{3+}$ precipitate at $\mathrm{pH}>3.5$. The ferric ion, when not involved in sulfide oxidation, precipitates as secondary mineral such as goethite. Dold and Fontboté [60] conducted chemical, mineralogical, and microbiological analyses on three Chilean copper porphyry ore deposit tailings in different climatic contexts (arid, semiarid, and humid). These tailings were classified as having low sulfidization and carbonate content. The comparison of the behavior of these three tailings shows that the climatic factor controls the direction in which the elements move, free from the chemical reactions in the tailings. For example, in a humid climate, the chemical elements in the tailings move from an oxidizing environment on the upper part to a reducing environment in the direction of the phreatic level. Meanwhile, in regions with an arid climate such as the Atacama Desert, transport is expected to occur in the inverse direction, which is toward a more oxidizing environment due to capillarity, thus forming secondary sulfates on the surface. This effect has also been observed in arid and semiarid environments, favoring oxidation processes and allowing efflorescent mineral formation (hydrated sulfates) on the tailing surface [61,62].

In the tailings studied, horizons a and b show a slightly acid $\mathrm{pH}$, while at depth $\mathrm{c}$, the $\mathrm{pH}$ is neutral. This suggests:

(i) As horizon a is more superficial, pyrite oxidizes, resulting in greater acidity (average $\mathrm{pH}=6.1$ ).

(ii) There is an enrichment of diamagnetic minerals such as silica toward horizon c; i.e., there is a greater neutralization potential $(\mathrm{pH}=7.05)$, which is supported by Si concentration increase with depth.

(iii) The formation of iron hydroxide should occur at the initial stage (pseudominerals) because, if minerals such as goethite were present in horizon c, the signal would increase owing to the high susceptibility of this mineral, which is not correlated with the MS tendency.

Horizontally, MS shows the highest concentration values at the ends and the lowest concentration values in the middle part of the terrace. Dold [63] indicates that, although tailings particle size is 
relatively homogeneous, there is a deposition controlled by sedimentological processes resulting in coarse granulometry near the deposition point (sulfides are heavier than silicates). According to this analysis, MS distribution maps show a certain coherence. High MS values may involve the presence of pyrite with positive susceptibility, while low values would be associated with diamagnetic materials such as silica or carbonates.

\subsection{Depth Variation of Chemical Elements}

As to the variation of chemical elements in the terrace, two factors control element mobility: solubility and $\mathrm{pH}[64,65]$. Solubility is a function of the chemical element concentration of the metal. In lower concentration systems, the elements are more mobile than in those with a higher concentration. Thus, mineralogical composition determines what chemical environment predominates and what elements are liberated and can mobilize [66-68]. In the terrace, $\mathrm{Cu}$ and $\mathrm{Cd}$ increase their concentration towards horizon c, similarly to the $\mathrm{pH}$. These behaviors are consistent, as reported by Dold and Fontbote [54], who determined that in tailings out of operation, the oxidation process occurs in its initial stage. Metals such as $\mathrm{Cu}, \mathrm{Pb}, \mathrm{Cd}, \mathrm{Ni}$, and $\mathrm{Ca}$ are quite mobile at a low $\mathrm{pH}$ and are adsorbed when $\mathrm{pH}$ increases, explaining the lower concentration in horizon $\mathrm{a}$, as compared with horizons $\mathrm{b}$ and c. The opposite is observed for $\mathrm{Zn}$ behavior, which mainly concentrates in horizon a. Dold and Fontboté [60] observed the same tendency in $\mathrm{Zn}$ and $\mathrm{Mg}$ in El Salvador tailings, which concentrate on the most superficial layer, corresponding to an evaporitic horizon with a high $\mathrm{pH}$.

\subsection{Relationship between Magnetic Susceptibility and Heavy Metal Concentration}

This relationship was analyzed with a MARS (multivariate adaptive regression splines) model suitable for this data structure. MARS was calculated by using the earth [69] library of the statistical package R [70], while the other statistical calculations were made with Minitab. Using data from Tables $3-5$, the relationship between MS and the concentrations of eight heavy metals was analyzed by using MARS, as in other engineering applications [71-75] because it fits these data better than other models [76,77].

The model is a MARS analysis, i.e., a type of regression introduced by Jerome Friedman [78]. It is a nonparametric regression technique that may be understood as a linear model extension automatically modeling nonlinear relationships and interactions between variables. In other words, it automatizes prediction model construction by selecting relevant variables, transforming predictive variables, treating missing values, and avoiding overfitting by means of an autotest. MARS is similar to a linear regression without splines.

It is mainly used for predicting a continuous variable $\vec{y}(n x 1)$, here MS, from a set of explanatory variables $\vec{X}(n x p)$, here the concentration of heavy metals. So, the MARS model may be represented by the expression $\vec{y}(n x 1)=f(\vec{X})+\vec{e}$, where $\vec{e}$ is an $(n x 1)$ error vector.

MARS analysis results in both a linear and a second-grade linear model, without higher-grade models.

In the linear model, a correlation is established between MS and the concentrations of four metals, $\mathrm{Cu}, \mathrm{Fe}, \mathrm{Ni}$, and $\mathrm{Cr}$, and no correlation obtained with the other heavy metals $\mathrm{Cd}, \mathrm{As}, \mathrm{Zn}$, and $\mathrm{Pb}$, meaning that the latter are not relevant for MS.

The correlation in this model is given by Equation (4):

$$
\begin{gathered}
\mathrm{MS}=0.55+7.2 \mathrm{e}^{-05} \times \operatorname{pmax}(0, \mathrm{Cu}-12207)-5.8 \mathrm{e}^{-05} \times \operatorname{pmax}(0,34756-\mathrm{Fe})- \\
0.02 \times \operatorname{pmax}(0,31-\mathrm{Ni})+0.076 \times \operatorname{pmax}(0,19-\mathrm{Cr})
\end{gathered}
$$

where pmax is 0 , if the other value is not positive. For example, pmax $(0,19-\mathrm{Cr})$ becomes 0 ; i.e., $\mathrm{Cr}$ does not influence the correlation until $\mathrm{Cr}$ concentration does not exceed $0.19 \mathrm{mg} \cdot \mathrm{kg}^{-1}$. 
MARS model parameters GCV $=0.047, \mathrm{RSS}=0.82, \mathrm{GRSq}=0.26$, and $\mathrm{RSq}=0.58$ show the model goodness of fit, $\mathrm{RSq}=0.58$, is not low for spread data.

The linear model, represented by pmax functions, shows that as Fe and Ni concentration increases, MS increases up to a certain value and then remains constant. For $\mathrm{Cu}$ concentration, MS remains constant up to a certain value and then increases. As for $\mathrm{Cr}, \mathrm{MS}$ decreases to a certain concentration value and then remains constant (Figure 4).
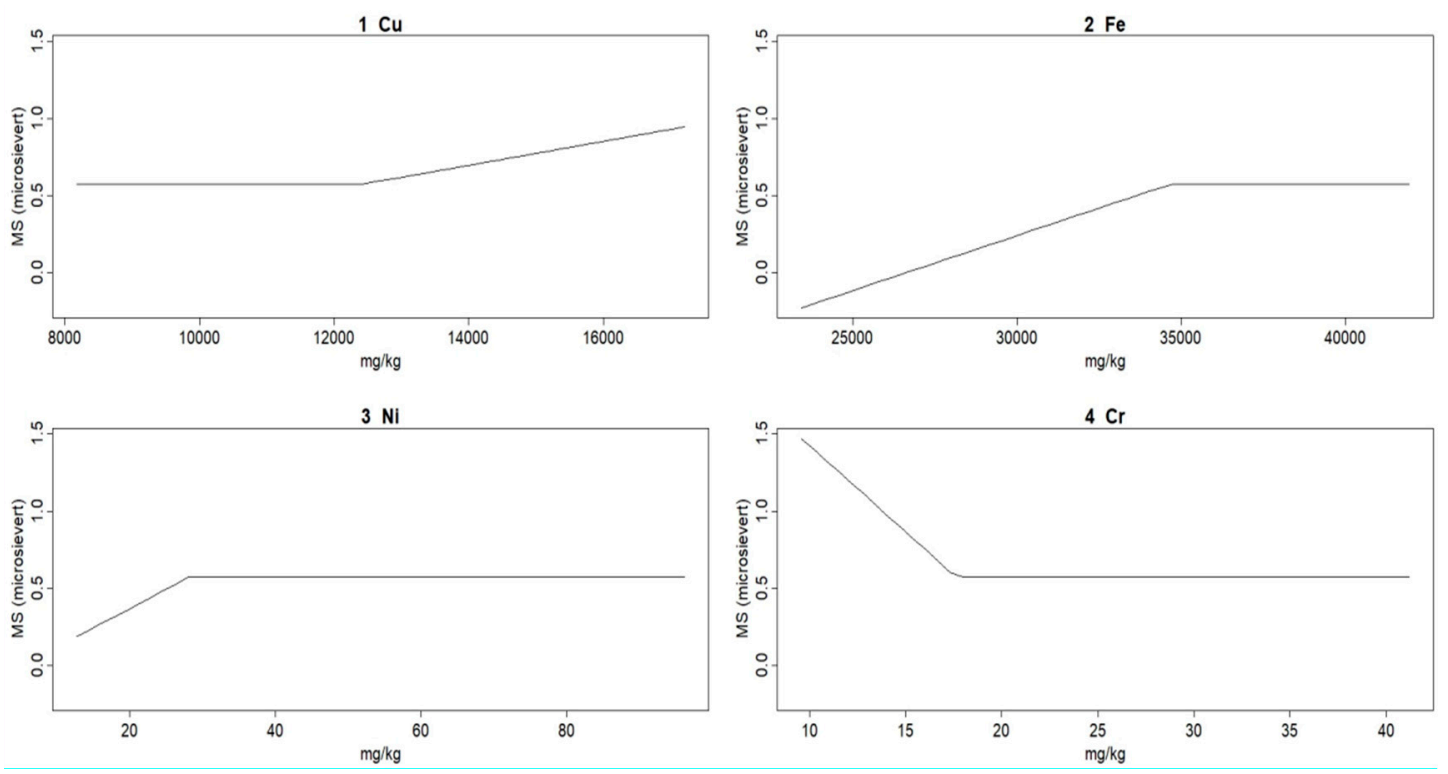

Figure 4. Relationship between metal concentration and magnetic susceptibility, discriminated by pmax functions.

In the second-grade model, the correlation is established between MS and the concentrations of three metals, $\mathrm{Cu}, \mathrm{Zn}$, and $\mathrm{Cr}$, the latter only as a second-order term. No correlation is obtained for the other heavy metals. This means that they are not relevant for MS. The fit is better than the one for the first-order model, with RSq slightly over 0.67 . The correlation of the second-grade model is given by Equation (5):

$$
\begin{gathered}
\text { MS }=0.43682171+0.00981946 \times \operatorname{pmax}(0, \mathrm{Zn}-287.2)+0.00981946 \times \operatorname{pmax}(0, \mathrm{Cu}-0.9323)+ \\
\operatorname{pmax}(0,287.2-\mathrm{Zn}) \times \mathrm{Cu}-0.00000040 \times \operatorname{pmax}(0, \mathrm{Zn}-287.2) \times \mathrm{Cu}- \\
0.00000089 \mathrm{Zn} \times \operatorname{pmax}(0,17.3-\mathrm{Cr}) \times 0.00022912
\end{gathered}
$$

MARS model parameters GCV $=0.05631133$, RSS $=0.6488601$, GRSq $=0.112011$, and $\mathrm{RSq}=0.670256$ show that the model goodness of fit, $\mathrm{RSq}=0.67$, is better than in the linear model.

Figure 5 shows $\mathrm{Zn}$ and $\mathrm{Cu}$ linear relationships and $\mathrm{Cr}$ second-order relationship. 

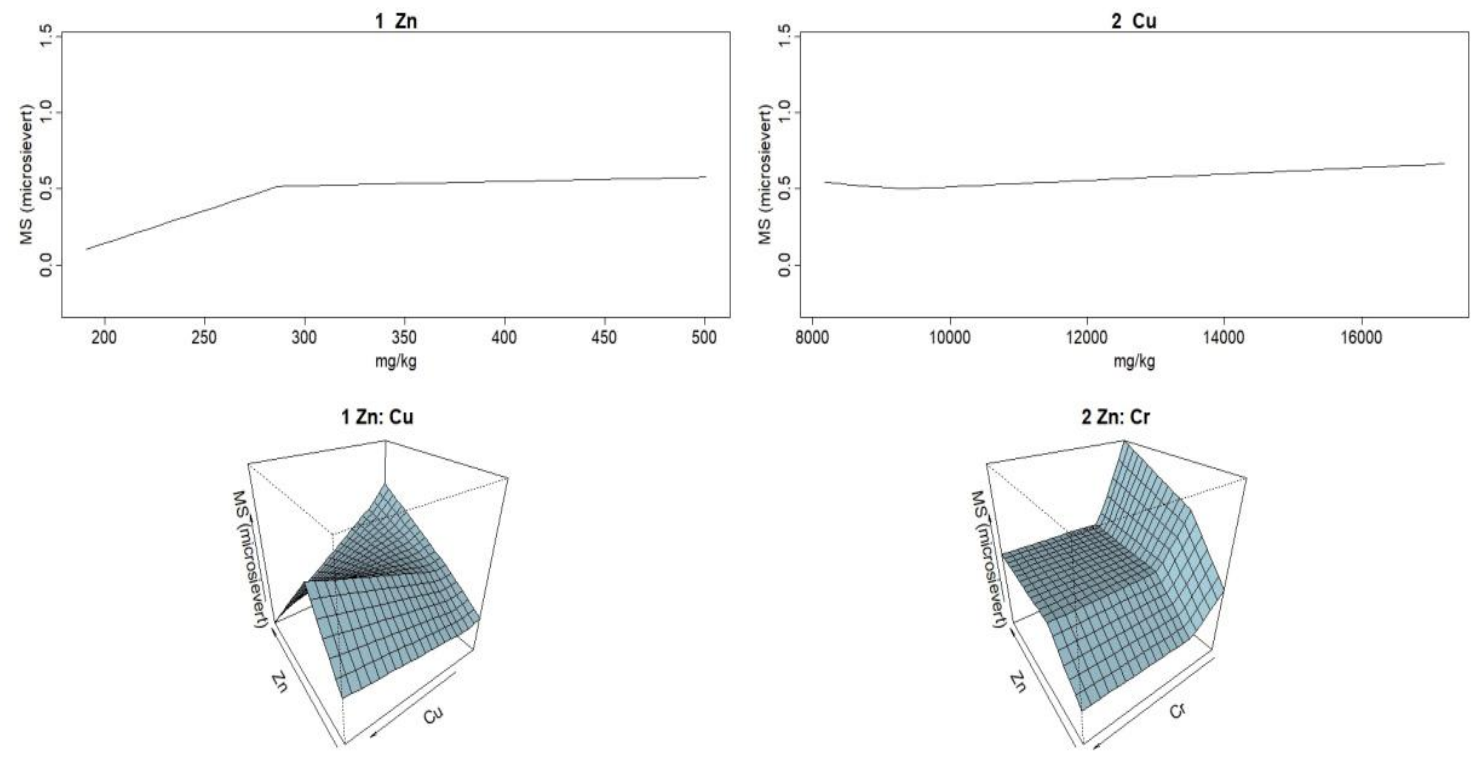

Figure 5. Relationship between metal concentration and magnetic susceptibility.

\subsection{MS Advantages over Metal Concentration}

The great advantage of susceptibility measurements is their promptness and low cost [79-81]. MS was directly measured in the substrate at $0-10,10-20$, and $20-30 \mathrm{~cm}$ depths. For each level, MS was measured at least three times at three different points. Then, the average was determined. The sediment was extracted with a plastic shovel to avoid changing magnetic measurements [82]. The technique results in the lowest cost, as compared with every other type of test and is little invasive for the environment. The chemical analysis was more complex, involving soil homogenization, clod disaggregation, and the removal of larger stones and residues. This was followed by clay content drying and sample sieving. Pretreatment for chemical analysis took about 3 days per sample $[5,6]$. So, preparing the sample for magnetic susceptibility is much simpler than preparing it for a chemical analysis. In addition, time must also be considered. As to MS, it is possible to measure 6 samples in $1 \mathrm{~h}$ on an average, considering the pretreatment stage. So, $40 \mathrm{~h}$ are required for the 240 sampling points. Thus, by working $8 \mathrm{~h} /$ day, 5 days are needed to obtain results. As to concentrations, pretreatment is more demanding and takes longer. For a further description, 6 samples can be collected each hour, the samples requiring at least a 3-day treatment. So, if 48 samples are collected daily, considering $8 \mathrm{~h}$ of work/day and 3 additional days for pretreatment, 4 days are required for collecting and treating 48 samples. Hence, for the 240 sampling points 20 days are required. In brief, the MS measurement of 240 points takes 5 days, while collecting and pretreating the 240 samples for measuring concentration takes 20 days. In addition, 3 months are necessary to measure the samples in the laboratory. So, for the time ratio required, concentrations:MS $=110: 5=22$, i.e., $2100 \%$ extra time for the characterization process. Table 7 shows the time necessary for measuring magnetic susceptibility and the chemical analysis of 240 sampling points. The chemical analysis considers the determination of eight heavy metals (As, Cd, $\mathrm{Cu}, \mathrm{Fe}, \mathrm{Hg}, \mathrm{Pb}$, and $\mathrm{Zn}$ ). 
Table 7. Time for determining MS and the concentration of 8 heavy metals in 240 samples.

\begin{tabular}{ccccc}
\hline \multirow{2}{*}{ No. of Samples } & MS Measurement Time & \multicolumn{2}{c}{ Time for the Concentration Measurement of 8 Heavy Metals } \\
\cline { 2 - 5 } & $\begin{array}{c}\text { Sample Collection and } \\
\text { Measurement in Situ }\end{array}$ & Sample Collection & Pretreatment & Measurement \\
\hline 6 & $1 \mathrm{~h}$ & $1 \mathrm{~h}$ & 3 days & 45 days \\
48 & 1 day & 1 day & 3 days & 45 days \\
240 & 5 days & 5 days & 15 days & 90 days \\
\hline $\begin{array}{c}\text { Time for MS } \\
\text { measurement of } \\
240 \text { points }\end{array}$ & 5 days & Time for collection, pretreatment, and & 110 days \\
\hline
\end{tabular}

The cost of measuring each MS is about 3 USD, while the cost of the chemical analysis of a sample is about 150 USD. For the cost required relationship, chemical analysis:MS $=1: 50$ USD, i.e., the cost of chemical analyses would be about $4900 \%$ higher than the cost of measuring an MS point.

Although it is not possible to measure all the sampling points only with MS, the number of points may decrease if MS can be correlated with the concentration. This renders significant savings, as in this study, where only 33 out of the 240 points were measured, producing savings of more than 30,000 USD.

\section{Conclusions}

MS measurements may provide further data about soil pollution to estimate the environmental situation in a study area; i.e., magnetic properties show depth variations, which reflect concentration changes, depth being an environmental soil pollution indicator.

A positive linear correlation of magnetic susceptibility with $\mathrm{Cr}, \mathrm{Fe}, \mathrm{Ni}$, and $\mathrm{Cu}$ was observed in the tailings studied, while in the second-grade model a correlation was found for $\mathrm{Cu}, \mathrm{Zn}$, and $\mathrm{Cr}$. These heavy metals, well-known as the most hazardous elements, are easily extracted by plants from the soils in the area studied [9]. In addition to traditional geochemical mapping, magnetic susceptibility could be successfully used for determining heavy metal soil pollution in the neighborhood of the site under study.

In the second-grade model, $\mathrm{R} 2$ is 0.67 . For this kind of problem with spread data, this is not a low value and, therefore, indicates a value correlation between heavy metal concentration and magnetic susceptibility. This correlation is important because the cost of measuring MS is much lower than making chemical analyses for heavy metal concentration. Therefore, an indirect method can be used to assess the presence of heavy metals in tailings without conducting chemical analyses, or perhaps just making a few analyses that may serve as a pattern to calibrate magnetic susceptibility, which has been shown to vary with depth.

The concentration and mobility of chemical elements in the tailings is mainly controlled by $\mathrm{pH}$. The interpretation of this and magnetic data enables detecting the chemical processes in the tailings, such as pyrite oxidation. MS is a good indicator because, as it decreases with depth, it is possible to interpret a greater concentration of diamagnetic minerals toward horizon c, which is complemented by the increasing depth of $\mathrm{Cu}$ concentrations.

Tailings sediments correspond to paramagnetic rather than diamagnetic arrangements, where ferromagnetic materials are present in small amounts within the paramagnetic matrix. The grain size of the tailings sediments does not allow a macroscopic recognition. So, for interpreting and understanding the magnetic signal, a detailed mineralogy control is necessary.

The correlation functions obtained can be used as semiquantitative tools for detecting toxic substance formations resulting from chemical reactions.

Magnetic methodologies, along with a small number of chemical analyses on representative samples, make it possible to develop sampling grids with a high spatial resolution at a low cost, thus decreasing costs associated with characterization.

Moreover, the potential use of these measurements to assess the metallic values contained in disposal facilities makes up an issue for further studies. 
Author Contributions: Conceptualization, E.J.L., R.C., R.G., Í.L.M., and E.E.V.; methodology, E.J.L., R.C., R.G., Í.L.M., and E.A.V.; validation, E.J.L. and R.G.; formal analysis, A.B., F.A.Á., and M.C.; investigation, E.J.L., R.C., R.G., Í.L.M., and E.A.V.; data curation, A.B., F.A.Á., and M.C.; writing-original draft preparation, E.J.L.; writing—review and editing, E.J.L.; visualization, E.J.L., R.G., Í.L.M., and M.C.; project administration, E.J.L. All authors have read and agreed to the published version of the manuscript.

Funding: This research was funded by CORFO-INNOVA project (08CM01-05), titled “Integrated development of magneto-chemical technologies and phytotechnologies applied to the remediation of heavy metals in the development of mining environmental liabilities".

Acknowledgments: The authors are thankful to CORFO-INNOVA project (08CM01-05), titled "Integrated development of magneto-chemical technologies and phytotechnologies applied to the remediation of heavy metals in the development of mining environmental liabilities", for the financial support of this project.

Conflicts of Interest: The authors declare no conflict of interest.

\section{References}

1. Park, I.; Tabelin, C.B.; Jeon, S.; Li, X.; Seno, K.; Ito, M.; Hiroyoshi, N. A review of recent strategies for acid mine drainage prevention and mine tailings recycling. Chemosphere 2019, 219, 588-606. [CrossRef] [PubMed]

2. Tabelin, C.B.; Silwamba, M.; Paglinawan, F.C.; Mondejar, A.J.S.; Duc, H.G.; Resabal, V.J.; Opiso, E.M.; Igarashi, T.; Tomiyama, S.; Ito, M.; et al. Solid-phase partitioning and release-retention mechanisms of copper, lead, zinc and arsenic in soils impacted by artisanal and small-scale gold mining (ASGM) activities. Chemosphere 2020, 260, 127574. [CrossRef] [PubMed]

3. Huyen, D.T.; Tabelin, C.B.; Thuan, H.M.; Dang, D.H.; Truong, P.T.; Vongphuthone, B.; Kobayashi, M.; Igarashi, T. The solid-phase partitioning of arsenic in unconsolidated sediments of the Mekong Delta, Vietnam and its modes of release under various conditions. Chemosphere 2019, 233, 512-523. [CrossRef] [PubMed]

4. Huyen, D.T.; Tabelin, C.B.; Thuan, H.M.; Dang, D.H.; Truong, P.T.; Vongphuthone, B.; Kobayashi, M.; Igarashi, T. Geological and geochemical characterizations of sediments in six borehole cores from the arsenic-contaminated aquifer of the Mekong Delta, Vietnam. Data Brief. 2019, 25, 104230. [CrossRef] [PubMed]

5. Lam, E.J.; Cánovas, M.; Gálvez, M.E.; Montofré, Í.L.; Keith, B.F.; Faz, Á. Evaluation of the phytoremediation potential of native plants growing on a copper mine tailing in northern Chile. J. Geochem. Explor. 2017, 182, 210-217. [CrossRef]

6. Lam, E.J.; Gálvez, M.E.; Cánovas, M.; Montofré, Í.L.; Keith, B.F. Assessment of the adaptive capacity of plant species in copper mine tailings in arid and semiarid environments. J. Soils Sedim. 2017, 18, 2203-2216. [CrossRef]

7. Acosta, J.A.; Faz, A.; Martínez-Martínez, S.; Zornoza, R.; Carmona, D.; Kabas, S. Multivariate statistical and GIS-based approach to evaluate heavy metals behavior in mine sites for future reclamation. J. Geochem. Explor. 2011, 109, 8-17. [CrossRef]

8. Martin-Crespo, T.; Gomez-Ortiz, D.; Martín-Velázquez, S.; Martínez-Pagán, P.; De Ignacio, C.; Lillo, J.; Faz, Á. Geoenvironmental characterization of unstable abandoned mine tailings combining geophysical and geochemical methods (Cartagena-La Union district, Spain). Eng. Geol. 2018, 232, 135-146. [CrossRef]

9. Lam, E.J.; Gálvez, M.E.; Cánovas, M.; Montofré, I.L.; Rivero, D.; Faz, A. Evaluation of metal mobility from copper mine tailings in northern Chile. Environ. Sci. Pollut. Res. 2016, 23, 11901-11915. [CrossRef]

10. Lam, E.J.; Montofré, I.L.; Álvarez, F.A.; Gaete, N.F.; Poblete, D.A.; Rojas, R.J. Methodology to Prioritize Chilean Tailings Selection, According to Their Potential Risks. Int. J. Environ. Res. Pub. Heal. 2020, 17, 3948. [CrossRef]

11. Lark, M.; Hamilton, E.; Kaninga, B.; Maseka, K.K.; Mutondo, M.; Sakala, G.M.; Watts, M.J. Nested sampling and spatial analysis for reconnaissance investigations of soil: An example from agricultural land near mine tailings in Zambia. Eur. J. Soil Sci. 2017, 68, 605-620. [CrossRef]

12. Constantinescu, P.; Neagoe, A.; Nicoara, A.; Grawunder, A.; Ion, S.; Onete, M.; Iordache, V. Implications of spatial heterogeneity of tailing material and time scale of vegetation growth processes for the design of phytostabilization. Sci. Total Environ. 2019, 692, 1057-1069. [CrossRef] [PubMed] 
13. Corriveau, M.; Jamieson, H.E.; Parsons, M.B.; Campbell, J.; Lanzirotti, T. Direct characterization of airborne particles associated with arsenic-rich mine tailings: Particle size, mineralogy and texture. Appl. Geochem. 2011, 26, 1639-1648. [CrossRef]

14. Khelfaoui, M.; Medjram, M.S.; Kabir, A.; Zouied, D.; Mehri, K.; Chikha, O.; Trabelsi, M.A. Chemical and mineralogical characterization of weathering products in mine wastes, soil, and sediment from the abandoned $\mathrm{Pb} / \mathrm{Zn}$ mine in Skikda, Algeria. Environ. Earth Sci. 2020, 79, 1-15. [CrossRef]

15. Valencia, I.E.; Hernández, B.A. Muestreo de Suelos, Preparación de Muestras y Guía de Campo; Universidad Autónoma de México: Cuautitlán, México, 2002.

16. Eang, K.E.; Igarashi, T.; Kondo, M.; Nakatani, T.; Tabelin, C.B.; Fujinaga, R. Groundwater monitoring of an open-pit limestone quarry: Water-rock interaction and mixing estimation within the rock layers by geochemical and statistical analyses. Int. J. Min. Sci. Technol. 2018, 28, 849-857. [CrossRef]

17. Siqueira, D.S.; Marques, J.; Pereira, G.T.; Teixeira, D.D.B.; Vasconcelos, V.; De Carvalho, J.O.A.; Martins, E. Detailed mapping unit design based on soil-landscape relation and spatial variability of magnetic susceptibility and soil color. Catena 2015, 135, 149-162. [CrossRef]

18. Jordanova, D.; Jordanova, N. Thermomagnetic behavior of magnetic susceptibility-Heating rate and sample size effects. Front. Earth Sci. 2016, 3, 90. [CrossRef]

19. Lecoanet, H.; Lévêque, F.; Segura, S. Magnetic susceptibility in environmental applications: Comparison of field probes. Phys. Earth Planet. Inter. 1999, 115, 191-204. [CrossRef]

20. Dalan, R.A. A review of the role of magnetic susceptibility in archaeogeophysical studies in the USA: Recent developments and prospects. Archaeol. Prospect. 2008, 15, 1-31. [CrossRef]

21. Luo, L.; Nguyen, A.V. A review of principles and applications of magnetic flocculation to separate ultrafine magnetic particles. Sep. Purif. Technol. 2017, 172, 85-99. [CrossRef]

22. Heller, F.; Strzyszcz, Z.; Magiera, T. Magnetic record of industrial pollution in forest soils of Upper Silesia, Poland. J. Geophys. Res. Space Phys. 1998, 103, 17767-17774. [CrossRef]

23. Strzyszcz, Z.; Magiera, T. Magnetic susceptibility and heavy metals contamination in soils of Southern Poland. Phys. Chem. Earth 1998, 23, 1127-1131. [CrossRef]

24. Ďurža, O. Heavy metals contamination and magnetic susceptibility in soils around metallurgical plant. Phys. Chem. Earth A Solid Earth Geod. 1999, 24, 541-543. [CrossRef]

25. Lecoanet,H.; Lévêque, F.; Ambrosi, J.-P. Combination of magnetic parameters: An efficient way to discriminate soil-contamination sources (South France). Environ. Pollut. 2003, 122, 229-234. [CrossRef]

26. Yang, T.; Liu, Q.; Chan, L.; Cao, G. Magnetic investigation of heavy metals contamination in urban topsoils around the East Lake, Wuhan, China. Geophys. J. Int. 2007, 171, 603-612. [CrossRef]

27. Rachwał, M.; Magiera, T.; Wawer, M. Coke industry and steel metallurgy as the source of soil contamination by technogenic magnetic particles, heavy metals and polycyclic aromatic hydrocarbons. Chemosphere 2015, 138, 863-873. [CrossRef]

28. Rachwał, M.; Kardel, K.; Magiera, T.; Bens, O. Application of magnetic susceptibility in assessment of heavy metal contamination of Saxonian soil (Germany) caused by industrial dust deposition. Geoderma 2017, 295, 10-21. [CrossRef]

29. Wang, B.; Xia, D.; Yu, Y.; Chen, H.; Jia, J. Source apportionment of soil-contamination in Baotou City (North China) based on a combined magnetic and geochemical approach. Sci. Total Environ. 2018, 642, 95-104. [CrossRef]

30. Gómez-García, C.; Martín-Hernández, F.; López-García, J.Á.; Martínez-Pagán, P.; Manteca, J.I.; Carmona, C. Rock magnetic characterization of the mine tailings in Portman Bay (Murcia, Spain) and its contribution to the understanding of the bay infilling process. J. Appl. Geophys. 2015, 120, 48-59. [CrossRef]

31. Jordanova, D.; Goddu, S.R.; Kotsev, T.; Jordanova, N. contamination of alluvial soils near Fe-Pb mining site revealed by magnetic and geochemical studies. Geoderma 2013, 192, 237-248. [CrossRef]

32. De Matos, M.P.; Fontes, M.P.F.; Da Costa, L.M.; Martinez, M. Mobility of heavy metals as related to soil chemical and mineralogical characteristics of Brazilian soils. Environ. Pollut. 2001, 111, 429-435. [CrossRef]

33. Sarkar, S.; Sarkar, B.; Basak, B.B.; Mandal, S.; Biswas, B.; Srivastava, P. Soil Mineralogical Perspective on Immobilization/Mobilization of Heavy Metals. In Adaptive Soil Management: From Theory to Practices; Springer Science and Business Media LLC: Berlin/Heidelberg, Germany, 2017; pp. 89-102.

34. Esquenazi, E.L.; Norambuena, B.K.; Bacigalupo, Í.M.; Estay, M. Gof soil intervention values in mine tailings in northern Chile. PeerJ 2018, 6, e5879. [CrossRef] [PubMed] 
35. Ghorbani, Y.; Kuan, S.H. A review of sustainable development in the Chilean mining sector: Past, present and future. Int. J. Min. Reclam. Environ. 2016, 31, 137-165. [CrossRef]

36. Araya, N.; Kraslawski, A.; Cisternas, L.A. Towards mine tailings valorization: Recovery of critical materials from Chilean mine tailings. J. Clean. Prod. 2020, 263, 121555. [CrossRef]

37. Lam, E.J.; Keith, B.F.; Montofré, Í.L.; Gálvez, M.E. Necessity of Intervention Policies For Tailings Identified In The Antofagasta Region, Chile. Rev. Int. Contam. Ambient. 2019, 35, 515-539. [CrossRef]

38. Alpers, C.N.; Brimhall, G.H. Middle Miocene climatic change in the Atacama Desert, northern Chile: Evidence from supergene mineralization at La Escondida. GSA Bull. 1988, 100, 1640-1656. [CrossRef]

39. Alpers, C.N.; Brimhall, G.H. Paleohydrologic evolution and geochemical dynamics of cumulative supergene metal enrichment at La Escondida, Atacama Desert, northern Chile. Econ. Geol. 1989, 84, 229-255. [CrossRef]

40. Maturana, M.R.; Saric, N. Geologia y minerallzacion del yacimiento tipo porfido cuprifero Zaldivar, en los Andes del norte de Chile. Andean Geol. 1991, 18, 109-120.

41. Durza, O.; Gregor, T.; Antalova, S. The effect of the heavy metals soil contamination on magnetic susceptibility. Acta Univ. Carol. Geol. 1993, 37, 135-143.

42. Vamerali, T.; Bandiera, M.; Mosca, G. In situ phytoremediation of arsenic- and metal-polluted pyrite waste with field crops: Effects of soil management. Chemosphere 2011, 83, 1241-1248. [CrossRef]

43. Rashed, M.N.; Awadallah, R.M. Trace elements in faba bean (Vicia faba L.) plant and soil as determined by atomic absorption spectroscopy and ion selective electrode. J. Sci. Food Agric. 1998, 77, 18-24. [CrossRef]

44. Berti, W.R.; Jacobs, L.W. Distribution of Trace Elements in Soil from Repeated Sewage Sludge Applications. J. Environ. Qual. 1998, 27, 1280-1286. [CrossRef]

45. Fellet, G.; Marchiol, L.; Perosa, D.; Zerbi, G. The application of phytoremediation technology in a soil contaminated by pyrite cinders. Ecol. Eng. 2007, 31, 207-214. [CrossRef]

46. Marchiol, L.; Fellet, G.; Perosa, D.; Zerbi, G. Removal of trace metals by Sorghum bicolor and Helianthus annuus in a site polluted by industrial wastes: A field experience. Plant. Physiol. Biochem. 2007, 45, 379-387. [CrossRef] [PubMed]

47. Clemente, R.; Dickinson, N.; Lepp, N.W. Mobility of metals and metalloids in a multi-element contaminated soil 20years after cessation of the pollution source activity. Environ. Pollut. 2008, 155, 254-261. [CrossRef]

48. Lindsay, W.L.; Norvell, W.A. Development of a DTPA Soil Test for Zinc, Iron, Manganese, and Copper. Soil Sci. Soc. Am. J. 1978, 42, 421-428. [CrossRef]

49. Tukey, J.W. Comparing Individual Means in the Analysis of Variance. Biometrics 1949, 5, 99. [CrossRef]

50. Kapicka, A.; Petrovský, E.; Ejordanova, D.; Podrázský, V. Magnetic parameters of forest top soils in Krkonoše mountains, Czech Republic. Phys. Chem. Earth A Solid Earth Geod. 2001, 26, 917. [CrossRef]

51. Hoffmann, V.; Knab, M.; Appel, E. Magnetic susceptibility mapping of roadside pollution. J. Geochem. Explor. 1999, 66, 313-326. [CrossRef]

52. Boyko, T.; Scholger, R.; Stanjek, H.; Team, M. Topsoil magnetic susceptibility mapping as a tool for pollution monitoring: Repeatability of in situ measurements. J. Appl. Geophys. 2004, 55, 249-259. [CrossRef]

53. Magiera, T.; Strzyszcz, Z.; Kapicka, A.; Petrovsky, E. Discrimination of lithogenic and anthropogenic influences on topsoil magnetic susceptibility in Central Europe. Geoderma 2006, 130, 299-311. [CrossRef]

54. Dold, B.S.; Fontboté, L. A mineralogical and geochemical study of element mobility in sulfide mine tailings of Fe oxide $\mathrm{Cu}-\mathrm{Au}$ deposits from the Punta del Cobre belt, northern Chile. Chem. Geol. 2002, 189, 135-163. [CrossRef]

55. Tabelin, C.B.; Veerawattananun, S.; Ito, M.; Hiroyoshi, N.; Igarashi, T. Pyrite oxidation in the presence of hematite and alumina: I. Batch leaching experiments and kinetic modeling calculations. Sci. Total Environ. 2017, 580, 687-698. [CrossRef] [PubMed]

56. Tabelin, C.B.; Veerawattananun, S.; Ito, M.; Hiroyoshi, N.; Igarashi, T. Pyrite oxidation in the presence of hematite and alumina: II. Effects on the cathodic and anodic half-cell reactions. Sci. Total Environ. 2017, 581, 126-135. [CrossRef] [PubMed]

57. Li, X.; Gao, M.; Hiroyoshi, N.; Tabelin, C.B.; Taketsugu, T.; Ito, M. Suppression of pyrite oxidation by ferric-catecholate complexes: An electrochemical study. Miner. Eng. 2019, 138, 226-237. [CrossRef]

58. Tomiyama, S.; Igarashi, T.; Tabelin, C.B.; Tangviroon, P.; Ii, H. Acid mine drainage sources and hydrogeochemistry at the Yatani mine, Yamagata, Japan: A geochemical and isotopic study. J. Contam. Hydrol. 2019, 225, 103502. [CrossRef] 
59. Igarashi, T.; Herrera, P.S.; Uchiyama, H.; Miyamae, H.; Iyatomi, N.; Hashimoto, K.; Tabelin, C.B. The two-step neutralization ferrite-formation process for sustainable acid mine drainage treatment: Removal of copper, zinc and arsenic, and the influence of coexisting ions on fertilization. Sci. Total Environ. 2020, 715, 136877. [CrossRef]

60. Dold, B.S.; Fontboté, L. Element cycling and secondary mineralogy in porphyry copper tailings as a function of climate, primary mineralogy, and mineral processing. J. Geochem. Explor. 2001, 74, 3-55. [CrossRef]

61. Del Rio-Salas, R.; Ayala-Ramírez, Y.; Loredo-Portales, R.; Romero, F.; Molina-Freaner, F.; Minjarez-Osorio, C.; Pi-Puig, T.; Ochoa-Landín, L.; Moreno-Rodríguez, V. Mineralogy and Geochemistry of Rural Road Dust and Nearby Mine Tailings: A Case of Ignored Pollution Hazard from an Abandoned Mining Site in Semi-arid Zone. Nat. Resour. Res. 2019, 28, 1485-1503. [CrossRef]

62. Dold, B. Evolution of Acid Mine Drainage Formation in Sulphidic Mine Tailings. Minerals 2014, 4, 621-641. [CrossRef]

63. Dold, B.S. Speciation of the most soluble phases in a sequential extraction procedure adapted for geochemical studies of copper sulfide mine waste. J. Geochem. Explor. 2003, 80, 55-68. [CrossRef]

64. Shu, W.; Ye, Z.; Lan, C.; Zhang, Z.; Wong, M. Acidification of lead/zinc mine tailings and its effect on heavy metal mobility. Environ. Int. 2001, 26, 389-394. [CrossRef]

65. Kovács, E.; Dubbin, W.E.; Tamás, J. Influence of hydrology on heavy metal speciation and mobility in a $\mathrm{Pb}-\mathrm{Zn}$ mine tailing. Environ. Pollut. 2006, 141, 310-320. [CrossRef]

66. Haffert, L.; Craw, D. Mineralogical controls on environmental mobility of arsenic from historic mine processing residues, New Zealand. Appl. Geochem. 2008, 23, 1467-1483. [CrossRef]

67. Tabelin, C.B.; Sasaki, R.; Igarashi, T.; Park, I.; Tamoto, S.; Arima, T.; Ito, M.; Hiroyoshi, N. Simultaneous leaching of arsenite, arsenate, selenite and selenate, and their migration in tunnel-excavated sedimentary rocks: I. Column experiments under intermittent and unsaturated flow. Chemosphere 2017, 186, 558-569. [CrossRef] [PubMed]

68. Tabelin, C.B.; Igarashi, T.; Villacorte-Tabelin, M.; Park, I.; Opiso, E.M.; Ito, M.; Hiroyoshi, N. Arsenic, selenium, boron, lead, cadmium, copper, and zinc in naturally contaminated rocks: A review of their sources, modes of enrichment, mechanisms of release, and mitigation strategies. Sci. Total Environ. 2018, 645, 1522-1553. [CrossRef] [PubMed]

69. Milborrow, S. Notes on the Earth Package. Available online: https://www.milbo.org/doc/earth-varmod.pdf (accessed on 23 June 2017).

70. R Core Team. R: A Language and Environment for Statistical Computing. 2018. Available online: https://www.r-project.org/ (accessed on 13 February 2012).

71. Nieto, P.G.; Lasheras, F.S.; Juez, F.D.C.; Fernández, J.A. Study of cyanotoxins presence from experimental cyanobacteria concentrations using a new data mining methodology based on multivariate adaptive regression splines in Trasona reservoir (Northern Spain). J. Hazard. Mater. 2011, 195, 414-421. [CrossRef] [PubMed]

72. Presno-Vélez, Á.; Bernardo-Sánchez, A.; Menéndez-Fernández, M.; Fernández-Muñiz, Z. Multivariate Analysis to Relate CTOD Values with Material Properties in Steel Welded Joints for the Offshore Wind Power Industry. Energies 2019, 12, 4001. [CrossRef]

73. Karimi, R.; Ayoubi, S.; Jalalian, A.; Sheikh-Hosseini, A.R.; Afyuni, M. Relationships between magnetic susceptibility and heavy metals in urban topsoils in the arid region of Isfahan, central Iran. J. Appl. Geophys. 2011, 74, 1-7. [CrossRef]

74. Harikrishnan, N.; Chandrasekaran, A.; Ravisankar, R.; Alagarsamy, R. Statistical assessment to magnetic susceptibility and heavy metal data for characterizing the coastal sediment of East coast of Tamilnadu, India. Appl. Radiat. Isot. 2018, 135, 177-183. [CrossRef]

75. Wang, X.S.; Qin, Y. Use of multivariate statistical analysis to determine the relationship between the magnetic properties of urban topsoil and its metal, S, and Br content. Environ. Earth Sci. 2006, 51, 509-516. [CrossRef]

76. Juez, F.J.D.C.; Lasheras, F.S.; Roqueñí, N.; Osborn, J. An ANN-Based Smart Tomographic Reconstructor in a Dynamic Environment. Sensors 2012, 12, 8895-8911. [CrossRef] [PubMed]

77. Ordóñez, C.; Lasheras, F.S.; Roca-Pardiñas, J.; Juez, F.J.D.C. A hybrid ARIMA-SVM model for the study of the remaining useful life of aircraft engines. J. Comput. Appl. Math. 2019, 346, 184-191. [CrossRef]

78. Friedman, J.H. Multivariate Adaptive Regression Splines. Ann. Stat. 1991, 19, 1-67. [CrossRef] 
79. Hanesch, M.; Scholger, R. Mapping of heavy metal loadings in soils by means of magnetic susceptibility measurements. Environ. Earth Sci. 2002, 42, 857-870. [CrossRef]

80. Siqueira, D.S.; Marques, J., Jr.; Matias, S.S.R.; Barrón, V.; Torrent, J.; Baffa, O.; Oliveira, L.C. Correlation of properties of Brazilian Haplustalfs with magnetic susceptibility measurements. Soil Use Manag. 2010, 26, 425-431. [CrossRef]

81. Ayoubi, S.; Adman, V.; Yousefifard, M. Use of magnetic susceptibility to assess metals concentration in soils developed on a range of parent materials. Ecotoxicol. Environ. Saf. 2019, 168, 138-145. [CrossRef]

82. Wawer, M.; Rachwał, M.; Kowalska, J. Impact of noise barriers on the dispersal of solid pollutants from car emissions and their deposition in soil. Soil Sci. Annu. 2017, 68, 19-26. [CrossRef]

Publisher's Note: MDPI stays neutral with regard to jurisdictional claims in published maps and institutional affiliations.

(C) 2020 by the authors. Licensee MDPI, Basel, Switzerland. This article is an open access article distributed under the terms and conditions of the Creative Commons Attribution (CC BY) license (http://creativecommons.org/licenses/by/4.0/). 